\title{
Pemeliharaan Planaria Dalam Perkembangbiakan Secara Vegetatif
}

\author{
Planaria in Vegetative Breeding \\ Hertien Koosbandiah Surtikanti \\ Jurusan Pendidikan Biologi \\ Program Studi Biologi, FPMIPA UPI, Jl. Dr. Setiabudhi 229 Bandung \\ E-mail: hertien_surtikanti@yahoo.com
}

\begin{abstract}
Test organism which is used for bioassay must fulfill some criteria such as: high sensitifity, widely available, wide distribution, biology background, successfully maintained in laboratory, and known history of culture in laboratory. This research has been done to study regeneration (vegetative) process of Planaria under laboratory condition. This is studied because of limited number of planaria population in clean freshwater. In order to study regeneration process, combination of two treatments (water conductivity and division-cutting type) were done to obtain optimum culture of Planaria. Four water conductivity $(100,200,300$ and $400 \mu \mathrm{S} / \mathrm{cm})$ and four division-cutting types (whole longitudinal, half longitudinal, transversal above pharynx and transversal mid-pharinx) were used. Each individual of Planaria was exposed with those treatments for 10 days (October, 2002). Initial and completed growth were observed. The result showed that, regeneration process of Planaria took 3-6 days to get full growth after transversal cutting (mid-pharynx). Whole summary revelead that Planaria is easy to maintain in laboratory. Therefore, Planaria may be used as an alternative bioindicator in evaluating water pollution.
\end{abstract}

Key words: Planaria, bioassay, conductivity, regeneration process

\begin{abstract}
Abstrak
Organisme percobaan yang digunakan sebagai bioindikator dalam uji hayati harus memenuhi beberapa persyaratan yaitu: memilki tingkat sensitivitas yang tinggi, mudah didapatkan di lapangan, memiliki latar belakang biologi yang sudah diketahui, dan dapat dikultur di laboratorium. Penelitian yang dilakukan di sini adalah studi tentang proses regenerasi dari planaria. Hal ini dimaksudkan karena jumlah planaria yang sangat terbatas di lapangan yang disebabkan oleh pencemaran sungai. Tujuan mempelajari proses regenerasi ini, adalah menentukan 2 perlakuan yaitu konduktivitas dan arah pemotongan planaria yang optimum dalam mendapatkan hasil generasi yang banyak. Empat jenis konduktivitas yaitu 100, 200, 300 and $400 \mu \mathrm{S} / \mathrm{cm}$ dan empat arah pemotongan yaitulongitudinal, setengah longitudinal, transversal di atas pharynx and transversal mid-pharinx. Masing-masing planaria diberi perlakuan secara kombinasi dan di inkubasi selama 10 hari pada suhu kamar (Oktober, 2002). Pengamatan dilakukan pada saat pertumbuhan awal dan sempurna. Hasil penelitian menunjukkan bahwa planaria membutuhkan 3-6 hari untuk mencapai pertumbuhan yang sempurna pada kondisi arah pemotongan mid-pharynx. Secara umum planaria dapat dijadikan alternatif untuk bioindikator uji hayati.
\end{abstract}

Kata kunci: Planaria, uji hayati, konduktivitas, arah pemotongan

Diterima: 05 Januari 2009, disetujui: 08 Januari 2010

\section{Pendahuluan}

Planaria sp. merupakan cacing pipih dengan panjang mencapai kurang lebih $30 \mathrm{~mm}$, umumnya ditemukan di habitat akuatik yang tidak tercemar dengan arus yang mengalir, sebab
Planaria sp. memerlukan oksigen yang baik, tidak bersifat asam (Hart et al., 1974) dan tidak mengandung bahan kimia organik bersifat polutan (Hynes, 1960). Planaria sp. merupakan bioindikator perairan bersih. Dari penelitian diketahui bahwa Planaria sp. ditemukan hanya 
di lokasi Sungai Cikapundung bagian hulu yang belum tercemar yaitu Bukit Tunggul dan Maribaya (Surtikanti et al., 2002). Kemudian pada studi lanjut diketahui bahwa dinamika populasi Planaria dipengaruhi oleh faktor lingkungan (Surtikanti, 2004a). Selain faktor lingkungan, keberadaan organisma tersebut dapat terancam kepunahan dengan semakin tinggi tingkat pencemaran air.

Dalam pengembangan metode uji hayati, planaria merupakan alternatif organisme uji dalam metode tersebut, selain menggunakan Daphnia (Dhahiyat, 1999) dan ikan air tawar (Pickering dan Henderson, 1966). Berdasarkan Rand dan Petrocelli (1975), Planaria sudah memiliki beberapa persyaratan sebagai hewan bioindikator dalam metode uji hayati: memiliki sensitifitas yang tinggi (Hynes, 1960; Hart et al., 1974, Surtikanti et al., 2002, dan Surtikanti, 2004b); mudah didapatkan dalam jumlah banyak diperairan tidak tercemar (Surtikanti, 2004a); asli menetap di habitat perairan tawar Indonesia; dan latar belakang biologi sudah diketahui (Surtikanti, 2004a). Sensitivitas Planaria juga sudah di teliti oleh Pagán et al., (2009) yang menyatakan bahwa Planaria dapat digunakan dalam mempelajari sistem syaraf, farmakologi dan toksikologi. Namun ada beberapa kriteria yang belum dipelajari yaitu: kesintasan planaria hidup dalam kondisi laboratorium, dan pemeliharaan planaria yang optimal didalam laboratorium. Hal ini disebabkan oleh keterbatasan jumlah planaria di perairan tawar, maka diperlukan ketersediaan planaria dalam bentuk pemeliharaan di laboratorium.

Planaria dapat berkembangbiak baik dengan cara seksual maupun aseksual. Secara seksual dilakukan dengan cara dua planaria dewasa saling melekat pada sisi ventral-posterior tubuhnya dan terjadi kopulasi (cross fertilisasi). Adapun secara aseksual, planaria membelah diri secara transversal, tiap-tiap belahan mengembangkan bagian-bagian yang hilang dan berkembang menjadi satu organisme utuh. Walaupun penelitian tentang proses aseksual ini sudah dilakukan (Temuryants et al., 2005 dan Sari, 2006), belum ada perlakuan arah pemotongan yang berbeda untuk mendapatkan planaria yang tumbuh dalam waktu yang singkat. Oleh sebab itu dalam penelitian ini akan dipelajari pemeliharaan planaria secara vegetatif.

\section{Metode Penelitian}

Penelitian ini dilakukan pada tanggal 20 September sampai 20 Oktober 2002. Pada awal penelitian, dilakukan pengambilan planaria terlebih dahulu di daerah Bukit Tunggul (Bandung Utara), bagian hulu dari Sungai Cikapundung. Planaria tersebut diaklimatisasi selama 1 minggu, dalam kondisi dan suhu ruangan di laboratorium Ekologi Jurusan Pendidikan Biologi UPI.

Pada tahap percobaan di laboratorium, Planaria diberi 2 jenis kombinasi perlakuan dengan menggunakan botol kaca $(10 \mathrm{~mL})$ (Gambar 2). Pertama, yaitu perlakuan terhadap 4 nilai konduktivitas yang berbeda yaitu 100, 200, 300 dan $400 \mu \mathrm{mS} / \mathrm{cm}$ dalam medium fresh water (ASTM). Penentuan nilai konduktivitas ini berdasarkan nilai konduktivitas yang ada di Bukit Tunggul (Surtikanti et al., 2002) yaitu sekitar $200 \mu \mathrm{mS} / \mathrm{cm}$. Kedua, yaitu perlakuan terhadap 4 arah pemotongan Planaria (Gambar 3) yaitu: (V1) memanjang pada seluruh tubuh, (V2) memanjang pada bagian kepala saja, (H1) melintang di tengah faring dan $(\mathrm{H} 2)$ melintang pada bagian anterior faring. Jumlah pengulangan untuk masing-masing keempat perlakuan tersebut yaitu 5 kali. Adapun Planaria untuk tiaptiap perlakuan dan ulangan yang digunakan satu individu. Selama perlakuan di laboratorium, planaria tersebut dikultur selama 10 hari, dengan pergantian medium air yang sudah diaerasi setiap hari. Selama percobaan tersebut, dilakukan pengamatan pada tingkat mortalitas setiap hari dan dicatat perkembangan yang terjadi yang meliputi pertumbuhan Planaria menjadi bentuk hingga sempurna. Selain itu juga dilakukan pengukuran parameter kualitas air yang meliputi konduktivitas, suhu dan $\mathrm{pH}$ untuk pengontrolan. Karena keterbatasan waktu dan tenaga, empat jenis perlakuan pemotongan tersebut dilaksanakan secara bertahap.

\section{Hasil dan Pembahasan}

Percobaan pada studi regenerasi (Tabel 1) terhadap planaria dilakukan secara bertahap. Ada empat jenis perlakuan arah pemotongan yang dilakukan yaitu: arah pemotongan melintang seluruh badan dan pada bagian kepala saja, serta 
arah pemotongan memanjang pada bagian tengah faring dan anterior faring. Hasil yang diperoleh ternyata arah pemotongan Planaria dapat memengaruhi lamanya pertumbuhan tunas pertama maupun pertumbuhan sempurna. Arah pemotongan secara melintang pada bagian tengah faring, lebih cepat terjadi regenerasi dibandingkan perlakuan yang lain. Waktu yang dibutuhkan sekitar 3-7 hari (Tabel 1). Dari hasil percobaan ini, maka daya regenerasi Planaria yang tinggi dapat dimanfaatkan dalam pemeliharaan Planaria di laboratorium.

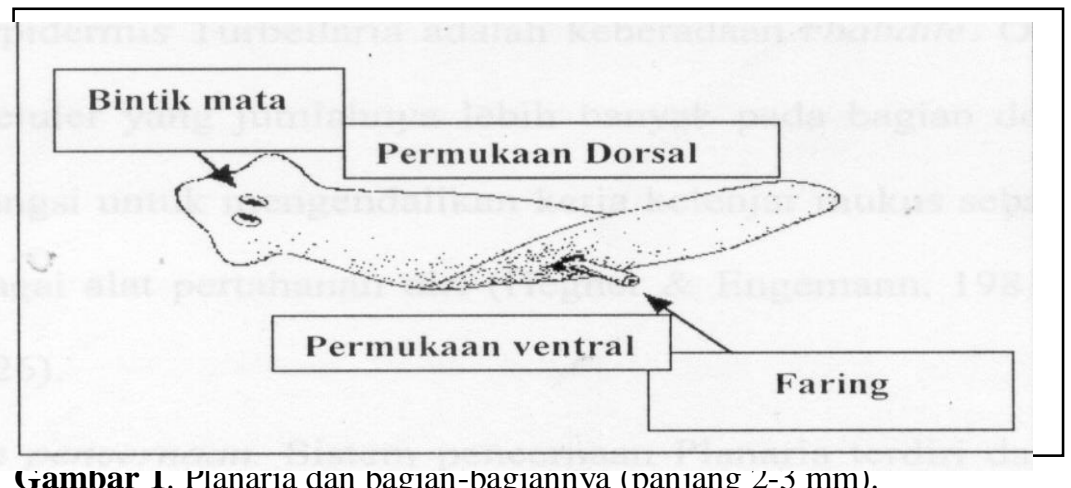

Gambar 1. Planarıa dan bagıan-bagıannya (panjang $2-5 \mathrm{~mm}$ ).

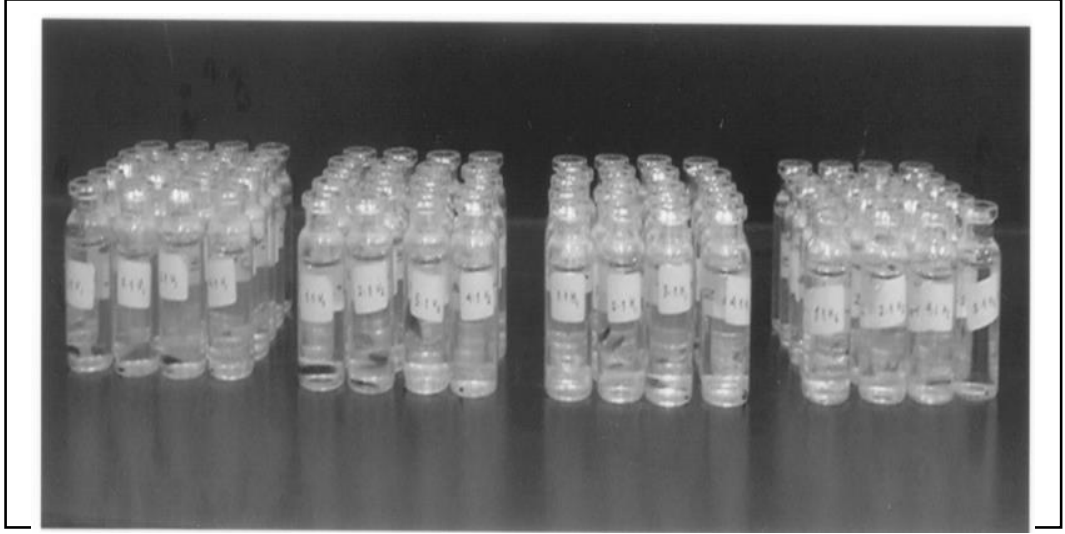

Gambar 2. Kultur planaria dengan menggunakan botol vial $10 \mathrm{~mL}$

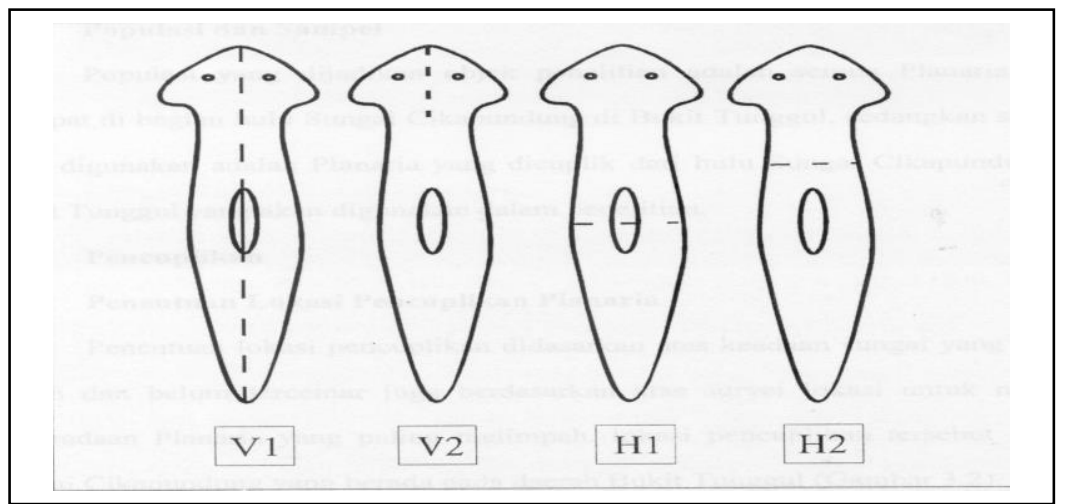

Gambar 3. Arah pemotongan Planaria: (V1) Memanjang pada seluruh badan, (V2) Memanjang bagian kepala, (H1) Melintang bagian tengah faring, (H2) Melintang bagian anterior faring.

Tabel 1. Waktu (hari) yang dibutuhkan Planaria pada proses regenerasi dengan 4 perlakuan arah pemotongan.

\begin{tabular}{lcc}
\hline \hline \multicolumn{1}{c}{ Perlakuan } & Tumbuh Tunas Pertama & Bentuk Sempurna \\
\hline \hline Memanjang pada seluruh badan & 5 & 10 \\
Memanjang pada bagian kepala saja & 5 & 9 \\
Melintang pada bagian tengah faring & 3 & 7 \\
Melintang pada bagian anterior faring & 4 & 7 \\
\hline \hline
\end{tabular}


Reddien dan Alvarado, 2004 menjelaskan bahwa proses regenerasi pada planaria terjadi karena adanya pertumbuhan jaringan baru dan perbanyakan sel (pembentukan blastema) pada permukaan kulit sel yang mengalami luka. Sel Planaria berukuran kecil dan memiliki nukleus yang besar dan mudah mengalami pembelahan sel stem neoblast. Hasil penelitian menunjukkan, jika pemotongan arah melintang pada tengah faring maupun anterior faring paling cepat mengalami pertumbuhan kembali. Hal ini disebabkan oleh adanya sel stem neoblast di sekitar organ tersebut, sebab berdasarkan Anonim (2007) bahwa tingkat kapasitas regenerasi sel mengindikasi adanya sel stem neoblast.

Konduktivitas air yang terdiri dari empat jenis yaitu $100,200,300,400 \mu \mathrm{mS} / \mathrm{cm}$, ternyata mempengaruhi daya sintas Planaria. Hal ini dapat dimaklumi sebab konduktivitas tinggi juga dapat meningkatkan nilai $\mathrm{pH}$ (Tabel 2) dan peningkatan kadar alkalinitas. Empat jenis konduktivitas ini dipilih berdasarkan nilai konduktivitas yang ada di lapangan (Bukit Tunggul dan Maribaya) sekitar $200 \mu \mathrm{S} / \mathrm{cm}$ dan medium freshwater yang sudah merupakan larutan standar untuk air tawar yang mengandung konduktivitas sekitar $400 \mu \mathrm{S} / \mathrm{cm}$. Ternyata dari hasil percobaan pada Tabel 3, daya sintas Planaria sangat bervariasi antara perlakuan arah pemotongan dan nilai konduktivitas. Namun pada konduktivitas $200 \mu \mathrm{S} / \mathrm{cm}$, daya sintas Planaria cukup tinggi mencapai $100 \%$ pada beberapa perlakuan arah pemotongan. Hal ini sesuai kondisi di lapangan yaitu Bukit Tunggul dimana konduktivitas sekitar $200 \mu \mathrm{S} / \mathrm{cm}$. Adapun konduktivitas yang tinggi memberikan indikasi kandungan ion yang sangat tinggi, kualitas air ini tidak cocok bagi kesintasan hidup planaria. Sesuai dengan hasil penelitian sebelumnya (Surtikanti et al., 2002) bahwa dibagian hilir sungai Cikapundung yang memiliki tingkat konduktivitas tinggi tidak diketemukan planaria.

Tabel 2. Rata-rata kualitas air (konduktivitas, suhu dan $\mathrm{pH}$ ) selama percobaan di laboratorium.

\begin{tabular}{ccc}
\hline \hline Konduktivitas $\boldsymbol{\mu m S / c m}$ & Suhu (C) & pH \\
\hline \hline 100 & 25,67 & 7,79 \\
200 & 25,33 & 8,01 \\
300 & 25,69 & 8,11 \\
400 & 25,21 & 8,33 \\
\hline \hline
\end{tabular}

Tabel 3. Daya sintas Planaria (\%) selama proses regenerasi terhadap variasi perlakuan dan nilai konduktivitas yang dikultur selama 10 hari.

\begin{tabular}{lrrrr}
\hline \hline \multicolumn{1}{c}{ Perlakuan } & $\mathbf{1 0 0} \boldsymbol{\mu m S / \mathbf { c m }}$ & $\mathbf{2 0 0} \boldsymbol{\mu} \mathbf{m S} / \mathbf{c m}$ & $\mathbf{3 0 0} \boldsymbol{\mu m S} / \mathbf{c m}$ & $\mathbf{4 0 0} \boldsymbol{\mu m S / c m}$ \\
\hline \hline Melintang pada seluruh badan & 96,25 & 85 & 75,50 & 68 \\
Melintang pada bagian kepala saja & 100 & 100 & 100 & 82 \\
Memanjang pada bagian tengah faring & 92,50 & 100 & 84,50 & 96,50 \\
Memanjang pada bagian anterior faring & 100 & 100 & 95 & 100 \\
\hline \hline
\end{tabular}

Keterangan: persentase daya sintas dihitung dari rata-rata 5 replikasi per individu.

\section{Simpulan dan Saran}

\section{Simpulan}

Proses regenerasi dengan arah pemotongan melintang tengah faring hanya memerlukan waktu 3-7 hari dan dapat diaplikasikan dalam usaha kultur Planaria di laboratorium. Penelitian ini perlu pengembangan lebih lanjut tentang proses perkembangbiakan Planaria secara vegetatif (aseksual), sebab hal ini diperlukan untuk memenuhi kebutuhan Planaria dalam kondisi homogen sebagai organisme percobaan untuk penelitian uji hayati di laboratorium. Nilai konduktivitas yang melebihi $200 \mu \mathrm{mS} / \mathrm{cm}$, tidak optimal untuk kesintasan planaria.

\section{Saran}

Saran dari hasil penelitian ini, bahwa pemeliharaan planaria di laboratorium ini dapat dikembangkan lagi dalam jumlah yang besar dan dalam jangka waktu yang lama. Sebab semakin tinggi tingkat pencemaran, dikhawatirkan jumlah planaria yang berada di lapangan akan semakin menyusut dan langka. Sangat disayangkan sekali. 


\section{Ucapan Terima Kasih}

Penelitian ini berlangsung atas Dana Rutin UPI tahun 2003, dan bantuan teknis yang dilakukan oleh mahasiswa, yakni Indri dan Rika Angkatan 1999.

\section{Daftar Pustaka}

Allan, J.D. 1995. Stream Ecology, Structure and Function of Running Waters. Chapman \& Hall. London. Annu. Rev. Cell Dev. Biol, 20: 725-57.

Anonim. 2007. Planaria Regeneration Activity. Howard Hughes Medical Institute.

Hart, C.W., Samuel, L.H. dan Fuller. 1974. Pollution of Freshwater Invertebrates. New York. Academic Press New York.

Hawkins, C.M. 1985. Populations Carbon Budgets and the Importance of the Amphipod, Corophium volutator in the Carbon Transfer on Cumberland Basin Mudflat, Upper Bay of Fundy, Canada. Netherlands J. of Sea Research, 19: $165-176$.

Hynes, H.B.N. 1960. The Biology of Polluted Waters. Liverpool University Press, Liverpool.

Nasir, M. 1999. Metode Penelitian. Jakarta Ghalia Indonesia.

Omori, K. dan Tanaka, M. 1998. Estimation of Maximum Density of a Mudflat Amphipod, Corophium volutator orientalis (Amphipoda, Crustacea) on the Basis of its Occupied Area. J. of Experimental Marine Biology and Ecology, 231: 31-45.

Peter, W., Reddien dan Alejandro, S.A. 2004. Fundamentals of Planarian Regeneration.
Rahkola, M., Karjalainen, J. dan Avinsky, V.A. 1998. Individual Weight Estimates of Zooplankton Based on Length-weight Regressions in Lake Ladoga and Saimaa Lake System. Nordic J. Freshw. Res, 74: 110-120.

Rand, G.M. dan Petrocelli. 1985. Fundamental of Aquatic Toxioclogy. Hemisphere Publishing Corporation. Washington.

Sari, N.D.A. 2006. Pertumbuhan Planaria yang Diperlakukan dengan Regenerasi Buatan di Sungai Semirang Ungaran. Skripsi Universitas Negeri Semarang.

Surtikanti, H.K. 2004a. Populasi Planaria di Lokasi Bukit Tunggul dan Maribaya, Bandung Utara. J. Matematika dan Sains, 9 (3): 259-262.

Surtikanti, H.K. 2004b. Pengujian Kualitas Air Sungai Cikapundung dengan Menggunakan Planaria, Chimera. J. Biologi, 9 (1): 31-40.

Surtikanti, H.K. 2008. Komunitas Benthos di Bukit Tunggul (DAS Cikapundung): Degradasi Pencemaran Sungai. Biosainstifika, I (1): 65-76.

Surtikanti, H.K., Kusumawaty, D. dan Hidayat, T. 2008 Monitoring DAS Cikapundung Bagian Hulu dengan Menggunakan Penanda DNA. Laporan Hibah Kompetensi DIKTI.

Surtikanti, H.K., Sumarno, U. dan Purwianingsih, W. 2002. Ecological Health Risk Assessment of Chemical in Water-Sediment of Cikapundung River System. Final report. Indonesia Toray Science Foundation.

Temuryants, N., Demtsun, N., Baranova, M. dan Yarmolyuk, N. 2005. Movement Dynamics of Planaria (Dugesia tigrina) Regenerating under Conditions of Electromegnetic Shielding. Taurida National V.I.Vernadsky University Simferopol, Crimea, Ukraine. 